\title{
Earthquake Disaster Mitigation in the Building Industry
}

\section{Noor Cholis Idham}

Department of Architecture, Universitas Islam Indonesia

\section{Article History}

Received : 11 September 2020

Accepted : 25 September 2020

Published: 05 October 2020

\begin{abstract}
Architects have a significant role in the building industry, starting from the initial plan to detailed construction and even adaptive reuse of the building. However, the safety issues related to building under an earthquake is usually going to the effort of making its integrity; thus, it commonly became the matter of engineer works and the construction process. This paper studies how actually architect plays a more significant part to deal with earthquake disaster in the complete cycles of building. The architect roles in building safety are discussed in every step in the building industry. It is clear enough that the architects are the ones mastering in every precaution related to the mitigation, from macro to micro, from start to finish, and from one to other aspects of the building. Neglecting one of those will only leave the occupants in danger.
\end{abstract}

Keywords: Architect role; Building safety; Earthquake disaster mitigation.

\section{Introduction}

Earthquakes are not the direct cause of loss of life and injuries, but the building failures. A disaster might occur because of multi-causal factors. However, earthquake-safe buildings are the most issues aiming for minimizing fatalities. Earthquake-resistant buildings, which focus more on the matter of structural strength, indeed different from building-safe concepts (Yashinsky, 2006). The building problems due to earthquakes is used to scope of the field of structure rather than others. The impact of an earthquake is often only discussed on the technical matters in the building strength calculation.

However, the building's safety is precisely determined not solely from the strength of its structure but also the overall building concepts. Millions of casualties might result from built environment failures (see table 1). Casualties were occurred frequently due to non-structural disintegration, such as object falling and insecure circulation pathways. A building could

Correspondence: Noor Cholis Idham

Department of Architecture, Universitas Islam Indonesia E-mail: noor.idham@uii.ac.id have been calculated based on a complete analysis on the structural system. However, in fact, moderate to large earthquakes almost always knocked down buildings and continued to take casualties (Boen, 2006). The high number of damages resulting thousands of victims such as 9.0 SR Tōhoku Japan March 3, 2011 with about 15,000 lives were lost and 125,000 buildings were destructed. Despite Japan is known as the readiest country against earthquake, the impact was still high. The magnitude 6.2 Yogyakarta 2006 earthquake on May 27th proves that there are still many traditional buildings made of wood that still stand up. On the other side, more than 25,0000 buildings made of bricks or reinforced concrete were destroyed, and the fatality reaches more than 6500 .

Up to the most recent time, there are proofs that structural calculations are not the only primary consideration in designing earthquakesafe buildings. Meanwhile, on the contrary, some buildings are not structurally stable planned, such as vernacular or traditional buildings, which have been proven to survive in earthquake shocks (Idham, 2019b). Many factors are influencing, such as the strength of the earthquake itself, epicenter distance, hypocenter depth, the geological conditions of the surrounding environment, and the building itself (Idham, 2019a). 
Table 1. Some of major earthquake and casualties resulted (Boano \& Hunter, 2012)

\begin{tabular}{|c|c|}
\hline Earthquakes & Casualties \\
\hline \multirow{3}{*}{$\begin{array}{l}\text { Gujarat India (2001) } \\
7.7 \mathrm{M}_{\mathrm{w}}\end{array}$} & $\begin{array}{l}25,000 \text { people dead and } \\
200,000 \text { injured, }\end{array}$ \\
\hline & $\begin{array}{l}600,000 \text { displaced or } \\
\text { homeless and }\end{array}$ \\
\hline & $\begin{array}{l}348,000 \text { houses destroyed } \\
\text { and } 844,000 \text { damaged }\end{array}$ \\
\hline $\begin{array}{l}\text { Aceh Indonesia } \\
\text { (2004) }\end{array}$ & $\begin{array}{l}167,900 \text { people dead, } 513,500 \\
\text { displaced and }\end{array}$ \\
\hline $9,1-9,3 M_{w}$ & 113,500 houses damaged \\
\hline $\begin{array}{l}\text { Kashmir Pakistan } \\
\text { (2005) }\end{array}$ & $\begin{array}{l}\text { 73,338 people dead and } \\
128,304 \text { injured, } 3.5 \text { million }\end{array}$ \\
\hline $7.6 \mathrm{M}_{\mathrm{w}}$ & $\begin{array}{l}\text { houses destroyed, and } \\
109,956 \text { damaged. }\end{array}$ \\
\hline Haiti (2010)ґ & 112.405 people dead and \\
\hline $7.0 \mathrm{M}_{\mathrm{w}}$ & $\begin{array}{l}\text { more, the } 197.000 \text { injured, } \\
\text { around } 4 \text { million people } \\
\text { affected, with almost } \\
1.000 .000 \text { of homeless. }\end{array}$ \\
\hline
\end{tabular}

The principle of earthquake-safe buildings allows buildings to be damaged or even collapse when a significant earthquake occurs, but the user should be safe. The impact of an earthquake on buildings must be examined concerning how an earthquake damages buildings. The nature and character of earthquake energy relate to the damage are significant concerns. For this reason, a thorough discussion is necessary to reduce the impact of the earthquake. We cannot directly compare the impact of two different earthquakes since many aspects are interrelated. However, the effects on different types of buildings can be analyzed in the same shock.

\section{Literature Review}

Why the buildings were knocked down from earthquakes? At least three aspects causing building failures under earthquake related to the scale of energy released, the intensity caused, and the readiness of the buildings. One single point may or may not create a disaster regarding the accumulative impact on the human environment.

The energy distribution of an earthquake affects the human environment at the surface of the earth. The power and intensity of the quake are related to the wave properties include the duration, amplitude, and frequency (Ghaidan, 2002). Following are the links of the aspects to their destructing capacity:

\section{a. Frequency and Amplitude}

A high-frequency earthquake has low amplitude and vice versa, so the frequency is inversely proportional to the amplitude. The amplitude reflects the strength of the earthquake, which affects the vibration. The distance and depth of the earthquake represented as the epicenter and hypocenter determine the amplitude. The shallower the earthquake, the higher the amplitude and its vibration energy. For example, a 3 Richter scale (RS) earthquake will have amplitude as $1 \mathrm{~mm}$ in $100 \mathrm{~km}$ distance and multiply ten times each increment of 1 RS (Krisnanto, 2009). The natural frequency of buildings is influenced by the size of the building, its structural system, and materials used. A flexible structure has a lower frequency than a rigid construction. Reinforcement can be done by adding rigid walls or bracing. The higher the energy of motion expressed in amplitude, the greater the movement of the building so that the top will experience displacement. As a result, the top of the building and its corners will be damaged first.

\section{b. Acceleration}

The acceleration of earthquake waves makes a heavyweight structure tends to maintain its position remain. The building strength, thus, as the primary key to keeping it still stands up. The May 27th, 2006 Yogyakarta earthquake acceleration at $3-5 \mathrm{~m} / \mathrm{sec} 2( \pm 0.5 \mathrm{~g})$ (Poland, 2010) damaged the residential building brick quickly. Exaggerated by with soft sedimentation soil, the acceleration folds 2-3 times (Walter et al., 2008) of $0.20 \sim 0.34 \mathrm{~g}$ horizontal and $3.5 \mathrm{~g}$ vertical (Amr S Elnashai, Kim, Yun, \& Sidarta, 2007). As a result, building damage was quite massive. Repeated vibrations accompanied by acceleration changes will impact on buildings by affecting the stability of structures. The dynamic movement of the soil will cause lateral and vertical forces in the building. The lateral load is more destructive compared to the vertical (Hamburger \& Scawthorn, 2006). However, for the case of the buildings located near the epicenter, the effect of the vertical force is more damaging due to the $\mathrm{R}$ wave causing the rolling of the soil surface. The combination of vertical and lateral forces in earthquakes creates reverse moments in buildings, particularly massive buildings (Ghaidan, 2002). 


\section{c. Earthquake Resonance}

The energy amplification caused by a resonance of its natural vibrating frequencies will more damage the buildings. An earthquake resonance occurs when its frequency match to the built environment. The resonance will increase the building vibration for energy amplification, thus experiencing more significant damage (Nikoloau, Gazetas, Garini, Diaz-Fanas, \& Ktenidou, 2018). Low buildings have high frequencies and vice versa. The natural frequency of the building 0.1 seconds means in one second it will take ten periods of vibration per floor, then the structure of single, 10,30 levels will have a frequency of $0.1,1$, 3 seconds, respectively. Thus the higher the building, the lower the natural frequency (figure 1).

Figure 1. The effect of a different frequency for different buildings (Idham, 2014)

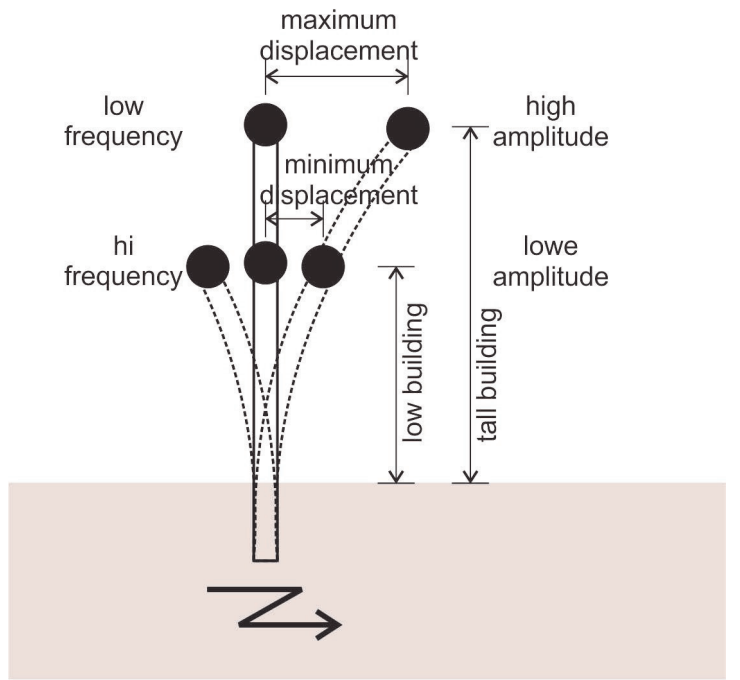

Proximity quakes will have more considerable energy comes from its high frequency compared to distant earthquakes. Affected more by its resonance due to high frequency, the nearby shorter buildings thus are the most vulnerable (figure 2).
Figure 2. The effect of resonance will be more for lower and rigid building

Source: author

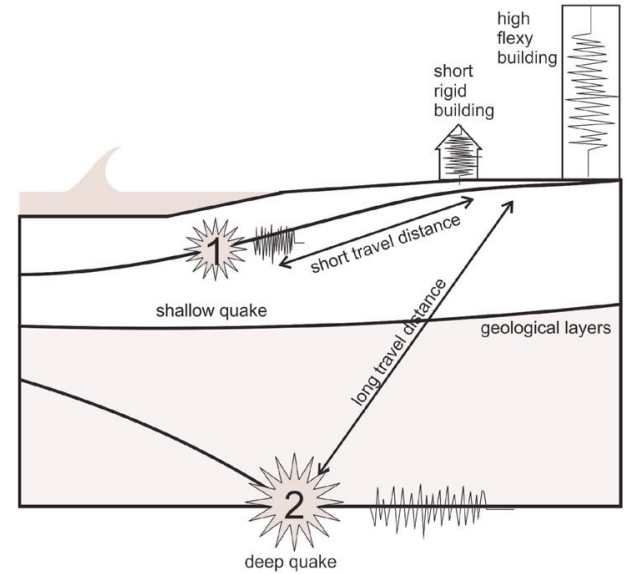

MMI (Modified Mercalli Intensity) scale intended to measure the effect on the human environment. Earthquake intensity is influenced by several reasons other than earthquake strength, namely, distance from hypocenter or epicenter, soil type, and duration time of the vibrations (figure 3 ). It is affected by distance, soil type, and duration of the quake.

Figure 3. The earthquake intensity and its damaging energy

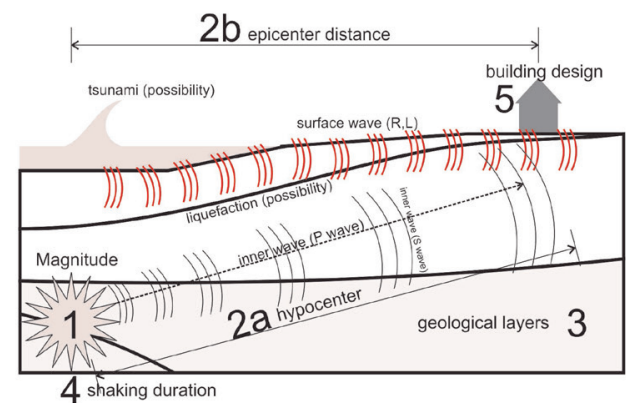

a. Effect of distance from the hypocenter or epicenter

Earthquake intensity is determined by the depth and length or hypocenter and epicenter of the earthquake source. The considered depth and range of the source are less than $70 \mathrm{~km}$ and $200 \mathrm{~km}$. A high magnitude earthquake will have a small intensity if the source is far away, but close and shallow quake will give significant effects, although the enormousness is less.

b. Effect of soil type

Waves will propagate quickly on hard soil and vice versa. Motion energy occurs in soft soils as a result of slowed wave velocity due to changes in the form of energy. An amplification 
arises at accelerating the propagation $<600 \mathrm{ft}$. /sec. Buildings stand on the soft soil will suffer more compared to those built on hard soil.

\section{c. Effect of earthquake duration}

The duration of the earthquake is very influential in the intensity of the buildings. Even though the strength is small, if it occurs for a long time, an earthquake can damage the building significantly. Long-time vibration will affect the durability of materials in the building structure. Therefore, aftershock quakes are also dangerous because they extend the impact time of the main earthquake.

An earthquake will begin to affect the building when the magnitude approaches $5.0 \mathrm{SR}$ resulting from the failure of the ground and the weak of structure (Yashinsky, 2006). The inability of parts of the building to work as a system will make a building collapsed (A.S. Elnashai \& Di Sarno, 2008). Design failures that affect the building structure performance related to its stiffness, strength, and ductility; because the connection is less precise; because of the quality of workmanship and materials, and because of soil failure whose physical structure has changed due to earthquake waves. These will be related to a massive structure, a short vibrational period of buildings, strength and ability of deformation, a progressive collapse, concentrated damage, vertical deviations, touching the adjacent buildings, contributions of inadequate architectural and non-structural elements, foundation failures, and declining quality and age (see example in figure 4).

Figure 4. Twisted upper part building and soft story failures (author)

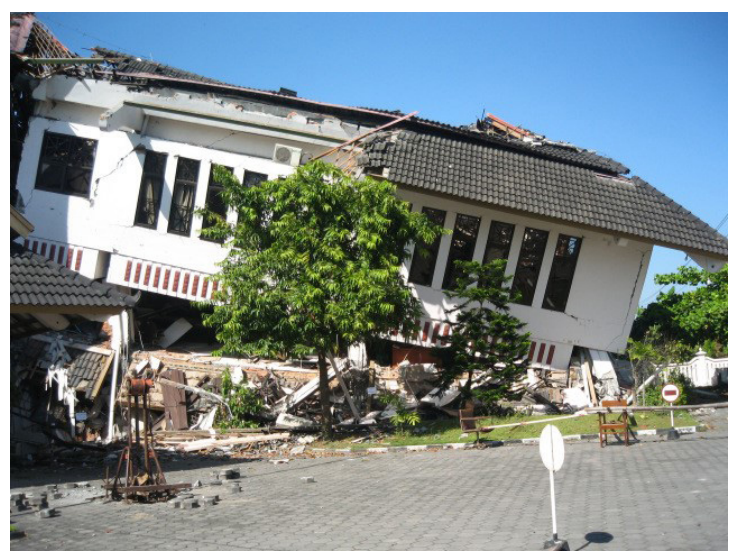

\section{Methodology}

This research examined firstly the properties of the earthquake and secondly how it affect the buildings in different circumstances. The result from the failures then linked by the role of the architect which is from the initial to the end of the building cycles. Several references were utilized from the field of earthquake as well as architectural design to construct the completed understanding of the architects and their responsibility in building safety.

\section{Result and Discussion}

Architect's duty on the facility has already developed covering from the initial to the post-occupation period. The need for Post Occupation Evaluation (POE) has been enlarged from the building and its operation to the whole process of the building industry. The three steps of POE have transformed into the six cycles of the architect's role broadened from a feasibility study to the adaptive use of the building (Preiser \& Nasar, 2008). The complete cycle is planning, programming, design, construction, occupation, and adaptive reuse (figure 5). Ahzahar.et.al. found that most of building failures were always involving the architects in most of the building cycle starting from fail on construction materials, faulty during construction, corruption, lack of supervision, faulty design, climatic condition, lack of maintenance, building type, and change in use, and location of building (Ahzahar, Karim, Hassan, \& Eman, 2011).

Figure 5. The six steps of building cycle involving architect as the main actor in the building industry (Preiser \& Nasar, 2008)

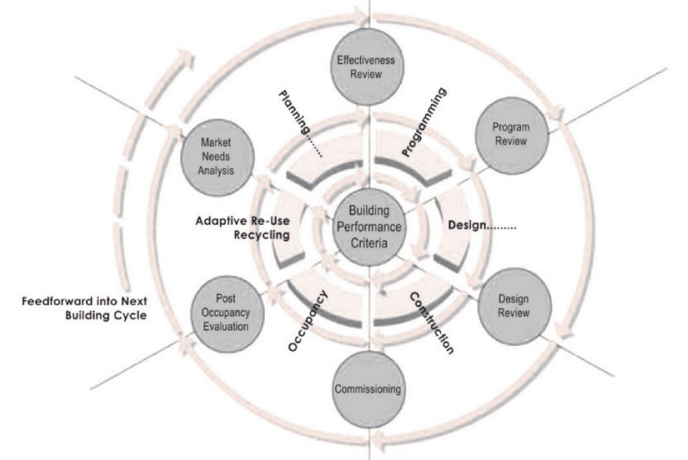

Planning is the first step of the role where an architect involves the initial project related to feasibility study and vision to long term considerations. Programming emphasizes the 
function of the building linked to the structure and infrastructure needed. Furthermore, the design will elaborate on the program in detailed planning. Construction executes the design on the field to make a plan become a reality. Occupation is the main aim of the building cycles, where the most live-span of the building. Adaptive reuse is needed when the original function was done, and the building still can be functioning. In all of the steps, the role of the architect is immense. The architect is the only profession that is involved comprehensively far before the building designing, occupying, and post function. Thus making it the master of the building who is has a high awareness for every aspect, including building safety.

\section{Safety issues on a planning}

Building planning holds a strategic part which considers the general aspects such as geographical and environmental condition. The location of the building will define the vulnerability circumstances according to the tectonic zone. Proximity to the ring of fire and soil solidity will directly affect the building integrity. An architect should detect the danger possibilities and react accordingly in this very early process of the building. Some aspects related to the planning are location and structural type.

\section{Location selection}

The location of the building should be considered related to the potential earthquake expected to come. The seismic zone is the key to understand the potential threat to the built environment. Proximity to the edge of the continent plate and its branch or fault along together affecting by the soil will affect the amount of energy transferred. The higher the magnitude, the more significant the power shifted. However, the magnitude is not the single causal factor to affect the built environment. The energy intensity that comes to the building is dependent on the distance and soil layer and its hardness. The harder the soil, the faster energy transfer, and the lower earth movement and vice versa. Amplification because of soil to building structure will destroy further the buildings (Mulibo, 2019). An architect should put the building away from the high-risk seismic zone and soft soil to avoid foundation failures. It will cause an utterly inhabitable structure even though the rest part of the building is left unaffected. The crash of the ground is also causing landslides, liquefaction, soil compaction, and differential forces.

\section{Structural type selection}

The short vibration period is identic with the lower structure, which will allow more number of swings during an earthquake. Short or rigid buildings have a high level of vulnerability except with a robust structural system. An architect may choose either facing a rigid and robust structure to absorb the strength of the force or allowing the energy transferred to a movement in a flexible structural system. Stiff and sturdy reinforced concrete or flexible and integrated wooden structure is a must for buildings located near to the high-risk zone from an earthquake.

Heavy-mass buildings such as constructed from bricks and reinforced concrete will create greater inertia when an earthquake occurs due to high amplitude. The inertia of the building is directly proportional to the mass of the structure. In the earthquake-prone area, architects should get rid of a massive building to elude the damage from the building itself. Instead, a light building is suggested to reduce the inertia-sway so the building will not result in self-destruction under an earthquake. The earthquakes such as in Java Indonesia 2006 or in Maden Turkey 2011 are the example of how the masonry buildings were easily collapsed from small earthquakes (Boen, 2006; Sayin, Yön, Calayir, \& Karaton, 2013).

\section{Safety issues on a programming}

Programming is further planning, which purposes to accommodate the building functions. Building configuration deals with the environment, neighborhood, and site are the primary determinant of the programming. Mass arrangement and room-space order related to function and its flow has to be considered. In emergency circumstances, these issues hold a significant role in safe people (Bernardini, D’Orazio, \& Quagliarini, 2016).

Hammering or blowing between two buildings many times will cause an impact on both structures, causing damaging and weakening building. This effect generally occurs in dense urban buildings. The proportion between the building height and space surrounding depend on the rigidity of the material of the structure. To be safe from the hammering effect, an architect should obey the neighborhood line between 
the site and building edges.

Multipurpose hall on the first level of the multistory building is eventually needed by opening the ground floor envelope and interior walls. Without appropriate reinforcement on the level, the weakest part of the building will direct to the floor. The architects should avoid blending the significantly different functions in one building. If needed, they should not get rid of most of the envelope and walls on the floor. Otherwise, the specific design should be applied, such as by enforcing the columns or by installing the bracing or shear walls.

\section{Safety issues on an architectural design}

As the conventional method, the heart of the architect works is in the building design, starting from general to detailed aspects. An architect is commonly responsible for staring from a site plan, building configuration, and building construction techniques. An architect has to deal with many disciplines in building construction, such as civil, mechanical, electrical engineering, and economic-social aspects.

\section{Building irregularities}

Vertical and horizontal building configuration will lead to the expected shortest path for the load in the structural elements. If the path is obstructed, the irregularities will arise. Damage due to deformation can occur on weak floors known as soft story. Wide openings on one of the levels also lead to the soft-story effect (Bhosale, Davis, \& Sarkar, 2017). The use of most fragile floors is often found in commercial or residential buildings by opening the ground floor walls for commercial or other purposes. Other vertical deviations can also occur due to a non-continuous column, building feedback, or a short column effect due to differences in height between different floors in high rise buildings or left open wall between the columns. Besides avoiding a soft story, the architect should use a simple grid structural system, a compacted building mass, and event-distributed column height.

Horizontal deviations are geometrical imbalances of the plan or asymmetries that cause unequal loads between the center of mass and the outside of the plan. The use of a complicated floor plan causes the midpoint of the building mass to vary with the outer wall can also create this effect. An architect should utilize a simple plan instead of complicated geometry for the building footprint. Separation or dilatation should be used if the architect needs the use of various forms in the building plan, so the response of the building will be independent.

\section{Building egress}

Evacuation, the building occupants, need the easiest and closest route to escape from the danger to a safe place. Design consideration must go to how to evacuate the occupants as soon as possible. Occupancy characteristics are the most factors for designing building egress (Bernardini et al., 2016). Corridors and fire stairs should serve the people without any significant hindrance. An architect should take into account the safety of egress routes by designing standard pathways for evacuation.

\section{Structural system and materials options}

The structural system is the ultimate key to save the building from quakes. The heavy structure should be avoided in high tectonic zones (FEMA 154, 2002). Contributions of inadequate architectural and non-structural elements also lead to a disaster. Improper architectural elements causing unbalanced parts will reduce structural system performance, such as wide openings, heavyweight roofs, and also massive walls. Inadequate architectural elements may lead to fatality trough to a crumbling wall, ceiling, and interior components. Brittle material such as concrete is still a popular material for its efficiency in the construction process and economic consideration. In another case, material availability also became problematic such as wood scarcity and steel affordability. The use of inappropriate materials far from the principles of stiffness, strength, and ductility will only shorten the building integrity under the quake (figure 6). 
Figure 6. Stiffness, strength, and ductility for different earthquakes (Idham, 2014)

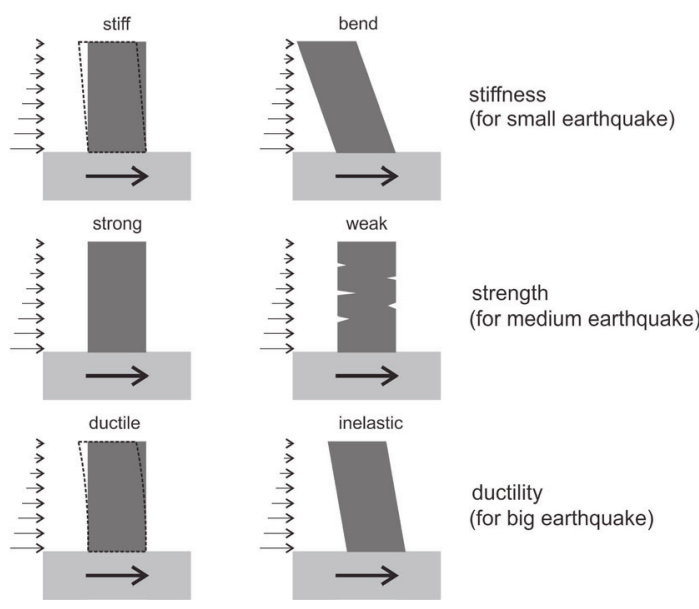

Construction details

Brittle materials encourage building failure, and a high strength material must be used. The mass of structure should be reduced to avoid deformation. The flexible building elements will reduce the tendency of deformation. The use of shear walls and the bracing system will enforce the building from deformations. A cantilever is also an element that should never be utilized exaggeratedly (FEMA 154, 2002).

The principle of structure with more strength in vertical than horizontal elements is known as a strong-column-weak-beam. The protection of the vertical components of the building, which support structure, can delay further collapse. Unfortunately, architects tend to prefer slender columns to make more space inside the building. Either big column or long shear wall is commonly non-preferable for architects since they may reduce their freedom in creativity.

\section{Safety issues on a building construction}

In a field construction, the plan and design should be executed without any significant alteration. A constructor must guarantee that they work based on the design document by the architect. The architect will take a role both to provide a construct-able drawing for the constructor guidance and to supervise their works.

Design clarity on the document is an inevitability, which is needed to guarantee the quality of field construction. An architect cannot rely on her/his imagination; instead, she or he has to explain the design concepts to the clear working drawings. The clarity of working design for the safety assurance from the architect is needed. Building Information Modelling is the current method to guarantee the design integrity, including dealing with safety.

Damage can occur in a part of a building, which will trigger further successive failures. Even other components or elements that are better still can be affected by this progressive collapse because of the accumulation of energy. Progressive collapse may arise by defect or low-quality building elements in the construction process. A field supervisor has to make sure that the quality is in homogeny.

\section{Safety issues on a building occupation}

In the building occupation, however, the role of an architect will evolve as a facility manager to maintain the quality of the building services. Any adjustment related to the use of the building should refer to the original plan of the design, so the accustomed newer function will not be much different.

Maintenance should be regularly done for safety assurance to maintain the quality of building integrity. Any defect of the building part due to maintenance error will directly decrease the strength of the building. Most of the failure due to building process mostly from; blemishes, corrosion, exterior surface fails, dampness, cracking, to falls foundation (Ahzahar et al., 2011). Structural defects will result in cracks or collapse, and the domino effect may result, such as progressive collapse due to an earthquake.

Though the building design already provides all precautions related to emergency, improper management for building safety may lead to fatality. Ease of egress for escaping from the disaster should be considered related hindrances such as corridor functions, furniture or interior elements configuration, and signage for egress guidance.

\section{Safety issues on an adaptive reuse}

An adaptive function may lead the catastrophic when the existing building unable to support the new load. Although reinforcement of the existing structure may be added to support new services, the architect should suggest the lighter function from the original design. Only in that way, the safety of the old building can be guaranteed. When the original purpose of the building is done, the vacant building thus either 
be demolished or reused for another function. Adaptive reuse, therefore, the procedure to adjust suitable new service to the existing condition of the building. Besides the proper maintenance is needed from the previous function, miscalculating newer reinforcement for the new function, and accumulated damages will only destroy the building (Błaszczyński \& Sielicki, 2019). The architect should not impose an incompatible adjustment. The whole loads for the adapted function of the old architecture should be the same or less than the previous one though reinforcement may be applied.

Age or aging, environmental conditions in buildings will decrease the quality of building materials and will reduce the strength of the building. A progressive collapse resulted from the fail of the weakest part of the building (Kanchanadevi \& Ramanjaneyulu, 2018; Yépez \& Yépez, 2017). Assessment of the whole building will detect any ongoing defect to prevent damage. Either incorrect design or unsuitable occupation may cause building vulnerability from the earthquake. $A$ comprehensive assessment should be done before reusing a building. FEMA 154 is one of the evaluations for earthquake vulnerability, which is a practical technique for architects (ATC, 2015). Rapid visual screening can be accessed for the general vulnerability of the facilities (Idham, 2011; Sarmah \& Das, 2018). A detailed examination may be needed from an engineer for further suspected weakness in the building.

\section{Conclusions}

This study concludes that in the architect roles starting from initiation the design to the reuse of old building always correlate with the building safety. Architects may involve in every phase of the building cycle or act partially according to the role. Any decision in every step will contribute to building safety. For this reason, an architect is one of the professions most responsible party starting from initial to the final of the building cycle. She or he holds coordinating functions to integrate all aspects of the building process. Leaving the building safety to other than an architect may lead to harmful and painful disasters.

Furthermore, architects should be aware of the nature of the earthquake. The issues of building failures are not solely dominated only by the engineer. As the main actor of the building design, they should know the behavior of the built environment under earthquake circumstances, although building integrity is a field in the area of the building engineer. As a designer, an architect should be capable of choosing which building type appropriate with the tectonic condition. In the earthquake-prone area, the first aim of the building design should go to the safety of the inhabitants. Other aspects related to the building design will follow after the assurance for the occupants is fulfilled. If all architects take all these considerations, we can ensure to decrease the earthquake threats on the built environment.

This paper is only examine the step of the building life-span by potential act under the architect roles by qualitative thinking. However, in every cycle, the deep evaluation need further research focusing on each by elaborated aspect, For this reason, further studies are still needed on the matter.

\section{References}

Ahzahar, N., Karim, N. A., Hassan, S. H., \& Eman, J. (2011). A study of contribution factors to building failures and defects in construction industry. In Procedia Engineering (Vol. 20, pp. 249-255). https:// doi.org/10.1016/j.proeng.2011.11.162

ATC. (2015). FEMA 153 (3rd ed.). Redwood City: NEHRP.

Bernardini, G., D’Orazio, M., \& Quagliarini, E. (2016). Towards a "behavioural design" approach for seismic risk reduction strategies of buildings and their environment. Safety Science, 86, 273-294. https://doi.org/10.1016/j.ssci.2016.03.010

Bhosale, A. S., Davis, R., \& Sarkar, P. (2017). Vertical Irregularity of Buildings: Regularity Index versus Seismic Risk. ASCEASME Journal of Risk and Uncertainty in Engineering Systems, Part A: Civil Engineering, 3(3). https://doi.org/10.1061/ AJRUA6.0000900

Błaszczyński, T. Z., \& Sielicki, P. W. (2019). The influence of design and contractor errors on the failure of a tenement building. Engineering Failure Analysis, 97, 676-689. https://doi.org/10.1016/j. engfailanal.2019.01.060

Boano, C., \& Hunter, W. (2012). Architecture at 
Risk (?): The Ambivalent Nature of Postdisaster Practice. Architectoni.Ca, 1(1), 1-13. https://doi.org/10.5618/arch.2012. v1.n1.1

Boen, T. (2006). Yogya Earthquake 27 May 2006, Structural Damage Report. Retrieved from https://www.eeri.org/lfe/pdf/ indonesia_yogya_structural_damage.pdf

Elnashai, A.S., \& Di Sarno, L. (2008). Fundamentals of Earthquake Engineering. England: A John Wiley \& Sons, Ltd, Publication.

Elnashai, Amr S, Kim, S. J., Yun, G. J., \& Sidarta, D. (2007). The Yogyakarta Earthquake of May 27, 2006. Retrieved from http:// mae.cee.illinois.edu/publications/reports/ Report07-02.pdf

FEMA 154. (2002). Rapid Visual Screening of Buildings for Potential Seismic Hazards. Redwood City: Applied Technology Council.

Ghaidan, U. (2002). Earthquake-Resistant Masonry Buildings; Basic Guidelines for Designing in Iran. Paris: UNESCO. Retrieved from http://unesdoc.unesco.org/ images/0013/001324/132475EB.pdf

Hamburger, R., \& Scawthorn, C. (2006). Seismic Design of Buildings, in Earthquake engineering for structural design. (W.-F. Chen \& E. M. Lui, Eds.). USA: Taylor \& Francis Group.

Idham, N. C. (2011). Seismic Vulnerability Assessment In Vernacular Houses: The Rapid Visual Screening Procedure for Non Engineered Building with Application to Java Indonesia. Eastern Mediterranean University.

Idham, N. C. (2014). Prinsip-Prinsip Desain Arsitektur Tahan Gempa. (Ignas, Ed.) (1st ed.). Yogyakarta: Penerbit Andi.

Idham, N. C. (2019a). Earthquake Failures on Buildings and the Role of Architect on Building Safety. DIMENSI (Journal of Architecture and Built Environment), 45(2), 153. https://doi.org/10.9744/ dimensi.45.2.153-164

Idham, N. C. (2019b). Indonesian Architecture and Earthquake Vulnerability: the Development of Building Safety through the Civilization. MATEC Web of Conferences, 280, 01004. https://doi.org/10.1051/ matecconf/201928001004

Kanchanadevi, A., \& Ramanjaneyulu, K. (2018). Effect of corrosion damage on seismic behaviour of existing reinforced concrete beam-column subassemblages. Engineering Structures,
174, 601-617. https://doi.org/10.1016/j. engstruct.2018.07.094

Krisnanto, E. (2009). Keandalan Struktur Bangunan terhadap Gempa Bumi Pada Bangunan Rumah Tinggal Padat Penduduk di Perkotaan. Jakarta: Jurusan Pendidikan Teknik Arsitektur Program Studi D3 Teknik Arsitektur Perumahan Fakultas Pendidikan Teknologi Dan Kejuruan Universitas Pendidikan Indonesia.

Mulibo, G. D. (2019). Investigation of macroseismic intensity of the Mw5.9 September 10, 2016 Kagera earthquake: Implications for site effect amplification. Journal of African Earth Sciences, 159. https://doi.org/10.1016/j. jafrearsci.2019.103568

Nikoloau, S., Gazetas, G., Garini, E., DiazFanas, G., \& Ktenidou, O.-J. (2018). Geoseismic Design Challenges in Mexico City. Structure Magazine, 10-14. Retrieved from https://www.structuremag. org/?p=13964

Poland, M. (2010). Localized Surface Disruptions Observed by InSAR during Strong Earthquakes in Java and Hawai'i. Bulletin of the Seismological Society of America, 100(2), 532-540. https://doi. org/10.1785/0120090175

Preiser, W. F. E., \& Nasar, J. (2008). Assessing Building Performance: Its Evolution from Post-Occupancy Evaluation. Article in International Journal of Architectural Research. https://doi.org/10.26687/ archnet-ijar.v2i1.179

Sarmah, T., \& Das, S. (2018). Earthquake Vulnerability Assessment for RCC Buildings of Guwahati City using Rapid Visual Screening. In Procedia Engineering (Vol. 212, pp. 214-221). Elsevier Ltd. https://doi. org/10.1016/j.proeng.2018.01.028

Sayin, E., Yön, B., Calayir, Y., \& Karaton, M. (2013). Failures of masonry and adobe buildings during the June 23, 2011 Maden(Elaziğ) earthquake in Turkey. Engineering Failure Analysis, 34, 779-791. https://doi. org/10.1016/j.engfailanal.2012.10.016

Walter, T. R., Wang, R., Luehr, B.-G., Wassermann, J., Behr, Y., Parolai, S., ... Zschau, J. (2008). The 26 May 2006 magnitude 6.4 Yogyakarta earthquake south of Mt. Merapi volcano: Did lahar deposits amplify ground shaking and thus lead to the disaster? Geochemistry, Geophysics, Geosystems, 9(5), n/a-n/a. https://doi.org/10.1029/2007GC001810 
Yashinsky, M. (2006). Earthquake damage to structures. In W. Chen \& E. Lui (Eds.), Earthquake engineering for structural design (pp. 1-58.). Boca Raton: Talyor \& Francis.

Yépez, F., \& Yépez, O. (2017). Role of construction materials in the collapse of R/C buildings after Mw 7.8 Pedernales Ecuador earthquake, April 2016. Case Studies in Structural Engineering, 7, 24-31. https://doi.org/10.1016/j.csse.2016.12.001 